\title{
PEMERIKSAAN STATUS GIZI PADA IBU HAMIL SEBAGAI UPAYA MENDETEKSI DINI KURANG ENERGI KRONIK (KEK)
}

\author{
Intan Sari ${ }^{*}$, Ana Sapitri ${ }^{2}$ \\ ${ }^{1,2}$ Akademi Kebidanan Budi Mulia Prabumulih \\ (intannadhifa215@gmail.com)*
}

\begin{abstract}
ABSTRAK
Latar Belakang: Pertumbuhan janin dapat dipengaruhi oleh status gizi ibu sebelum dan selama hamil. World Health Organization (WHO) menyatakan bahwa prevalensi ibu hamil yang mengalami Kurang Energi Kronik (KEK) cenderung terjadi negara berkembang daripada negara maju. Salah satu masalah gizi umum pada ibu hamil di Indonesia adalah kekurangan kalori protein.

Tujuan: Penelitian ini bertujuan untuk mengetahui pemeriksaan status gizi pada ibu hamil sebagai upaya mendeteksi dini Kurang Energi Kronik (KEK) di Puskesmas Sukajadi Prabumulih.

Metode: Desain pada penelitian ini adalah Action Research dimana peneliti harus mencantumkan plan (perencanaan), do (pelaksanaan), dan see (evaluasi). Populasi dalam penelitian ini adalah seluruh ibu hamil yang datang untuk memeriksakan kehamilannnya di Puskesmas Sukajadi Prabumulih pada Bulan Oktober tahun 2020. Teknik pengambilan sampel dalam penelitian ini adalah Purposive Sampling yaitu pengambilan sampel atas dasar pertimbangan dengan unsur-unsur yang dikehendaki sesuai dengan kriteria inklusi dengan jumlah sampel sebanyak 20 responden. Teknik pengumpulan data menggunakan checklist.

Hasil: Terdapat $13(65 \%)$ ibu hamil yang memiliki ukuran LILA $<23,5 \mathrm{~cm}$, dan terdapat $7(35 \%)$ ibu hamil yang memiliki ukuran LILA > 23,5\%. Sebanyak 12 (60\%) ibu hamil yang mengalami status gizi kurang dan terdapat 8 (40\%) ibu hamil yang memiliki status gizi baik.

Kesimpulan: Berdasarkan hasil penelitian dapat disimpulkan bahwa sebagian besar $(65 \%)$ ibu hamil memiliki LILA $<23,5 \mathrm{~cm}$ dan ibu hamil dengan status gizi kurang sebanyak $(60 \%)$.
\end{abstract}

Kata kunci: Status gizi, ibu hamil, Kurang Energy Kronik (KEK), LILA

\section{Examination of Nutritional Status of Pregnant Women As An Effort to Detect Early Chronic Energy Deficiency (CED)}

\begin{abstract}
Background: Fetal growth can be affected by the nutritional status of the mother before and during pregnancy. The World Health Organization (WHO) states that the prevalence of pregnant women experiencing Chronic Energy Deficiency (KEK) tends to occur in developing countries than in developed countries. One of
\end{abstract}


the common nutritional problems in pregnant women in Indonesia is a protein calorie deficiency

Objective: This study aims to determine the nutritional status examination of pregnant women as an effort to detect Chronic Energy Deficiency (KEK) early at the Sukajadi Prabumulih Health Center.

Method: The design in this research is Action Research where the researcher must include the plan (planning), do (implementation), and see (evaluation). The population in this study were all pregnant women who came to have their pregnancy checked at the Sukajadi Prabumulih Public Health Center in October 2020. The sampling technique in this study was purposive sampling, which is sampling based on consideration with the desired elements according to the inclusion criteria by the number of a sample of 20 respondents. The data collection technique uses a checklist.

Results: There were 13 (65\%) pregnant women who had a LILA size $<23.5 \mathrm{~cm}$, and there were 7 (35\%) pregnant women who had a LILA size > 23.5\%. A total of $12(60 \%)$ pregnant women had a malnutrition status and there were $8(40 \%)$ pregnant women who had a good nutritional status.

Conclusion: Based on the results of the study, it can be concluded that most (65\%) pregnant women have LILA $<23.5 \mathrm{~cm}$ and pregnant women with low nutritional status (60\%).

Keywords: Nutrisional Status, Pregnant women, Cronic Energy Deficiency (CED), Mid-Upper Arm Circumference (MUAC)

\section{PENDAHULUAN}

Aspek penting untuk menentukan apakah seorang ibu yang sedang hamil dapat melewati masa kehamilannya dengan baik dan tanpa ada gangguan apapun adalah dengan menilai status gizinya. Status gizi ibu hamil haruslah normal, karena ketika ibu hamil tersebut mengalami gizi kurang atau gizi berlebih akan banyak komplikasi yang mungkin terjadi selama kehamilan dan berdampak pada kesehatan janin yang dikandungnya. Salah satu permasalahan gizi ibu hamil adalah kekurangan energi kronik (KEK). Kekurangan energi kronis (KEK) adalah masalah gizi yang disebabkan karena kekurangan asupan makanan dalam waktu yang cukup lama, hitungan tahun. Berdasarkan Studi Diet Total (SDT) tahun 2014, gambaran asupan makanan ibu hamil di Indonesia masih memprihatinkan, dimana proporsi ibu hamil dengan tingkat kecukupan energi kurang dari $70 \%$ angka kecukupan energi (AKE) sedikit lebih tinggi di pedesaan dibandingkan dengan perkotaan yaitu sebesar 52,9\% dibandingkan dengan 51,5\%. Sementara proporsi ibu hamil dengan tingkat kecukupan protein kurang dari $80 \%$ angka kecukupan protein (AKP) juga lebih tinggi di pedesaan dibandingkan dengan perkotaan yaitu sebesar $55,7 \%$ dibandingkan $49,6 \%$. Kurangnya asupan energi yang berasal dari zat gizi makro (karbohidrat, protein dan lemak) maupun zat gizi mikro terutama vitamin A, vitamin $\mathrm{D}$, asam folat, zat besi, seng, kalsium dan iodium serta zat gizi mikro lain pada wanita usia subur yang berkelanjutan (remaja sampai masa kehamilan), mengakibatkan terjadinya Kurang Energi 
Kronik (KEK) pada masa kehamilan, yang diawali dengan kejadian 'risiko' KEK dan ditandai oleh rendahnya cadangan energi dalam jangka waktu cukup lama yang diukur dengan lingkar lengan atas (LILA). (Kemenkes RI, 2017).

Berdasarkan data dari Laporan Kinerja Ditjen Kesehatan Masyarakat Tahun 2017. Dinilai dari sasaran meningkatnya ketersediaan dan keterjangkauan pelayanan kesehatan yang bermutu bagi seluruh masyarakat, Indikator persentase ibu hamil dengan Kurang Energi Kronik (KEK) menunjukkan indikator negatif dengan nilai cakupan 14,8\% masih dibawah target capaian yang ditentukan yaitu 21,2\%.(Ditjen Kesmas Kemenkes, 2018)

Jumlah kasus status gizi buruk pda tahun 2018 mengalami kenaikan dalam empat tahun terakhir. Pada tahun 2014 jumah kasus gizi buruk di Sumatera Selatan sebanyak 276 orang, turun menjadi 162 orang pada tahun 2015 lalu naik menjadi 248 orang pada tahun 2016 dan naik kembali menjadi 277 orang pada tahun 2017 dan naik lagi menjadi 313 orang pada tahun 2018. Pada tahun 2018 jumlah kasus gizi buruk tertinggi terjadi di kabupaten OKU Timur sebanyak 95 orang, kabupaten Muara Enim 30 orang dan kabupaten Musi Rawas sebanyak 28 orang, kota Prabumulih 11 orang sedangkan jumlah kasus gizi buruk yang terendah terdapat di kota Palembang sebanyak 1 orang dan Kabupaten Musi Banyuasin sebanyak 2 orang dan kab. OKU serta kota Lubuk Linggau masingmasing sebanyak 3 orang, sedangkan di kabupaten Musi Rawas Utara tidak ada laporan kasus gizi buruk. (RKT, Dinas Kesehatan Dekon Sumsel, 2019).

Ada beberapa faktor penyebab ibu hamil mengalami KEK diantaranya adalah tentang pola makan yang tidak teraktur dan asupan zat gizi yang kurang sangat mempengaruhi kurangnya status gizi ibu hamil, hal ini dikarenakan selain tingkat pendidikan yang rendah, pendapatan sehari-hari keluarga ibu hamil sangat kecil sehingga ibu hamil tidak mampu untuk memenuhi zat gizi dalam tubuhnya.(Tanawani, 2015). Seorang ibu mengalami kekurangan gizi selama hamil akan menimbulkan masalah, baik pada ibu maupun janin yang dikandungnya, antara lain :anemia, perdarahan dan berat badan ibu tidak bertambah secara normal, kurang gizi juga dapat mempengaruhi proses persalinan dimana dapat mengakibatkan persalinan sulit dan lama, premature, perdarahan pasca persalinan, kurang gizi juga dapat mempengaruhi pertumbuhan janin terhambat dan dapat menimbulkan keguguran, abortus, cacat bawaan dan berat janin lahir rendah (Budi Iswanto dkk, 2012).

Ibu hamil dengan Kurang Energi Kronik pada batas $23 \mathrm{~cm}$ mempunyai resiko untuk melahirkan BBLR dibandingkan dengan ibu yang mempunyai LILA lebih dari 23,5 cm. Angka kejadian kelahiran premature yang disebabkan karena ibu hamil mengalami kurang gizi (kurang energi kronik), yang ditandai dengan lingkar lengan atas kurang dari $23,5 \mathrm{~cm}$ tidak signifikan. Akibat yang paling relevan dari ibu hamil kurang energi kronik adalah terjadinya bayi lahir dengan Berat Badan Lahir Rendah (BBLR) (Waryana, 2010).

Berdasarkan penelitian Suhaeti dkk (2018). Terdapat hubungan antara pola makan dengan status gizi ibu hamil dengan nilai $\mathrm{p}=0.001<0.05$ hal ini dikarenakan pola makan ibu hamil dapat memberikan asupan untuk tetap menjaga berat badan selama mengandung, makanan yang dikonsumsi harus banyak mengandung protein dan vitamin tujuannya agar terhindar dari kekurangan energi 
kronik yang dapat mempengaruhi status gizinya. Konsumsi energy dan protein yang kurang selama jangka waktu tertentu akan menyebabkan status gizi tidak normal atau mengalami KEK sehingga untuk menjamin kesehatan ibu hamil, maka perlu mengkonsumsi makanan yang mengandung protein dan vitamin selama masa kehamilan)..

Jumlah kunjungan ibu hamil di Puskesmas Sukajadi Prabumulih pada tahun 2017 sebanyak 1.379 ibu hamil dan terdapat 376 (24,2\%) kasus ibu hamil yang mengalami Kurang energi kronik, pada tahun 2018 sebanyak 1.478 ibu hamil dan terdapat $531(28,8 \%)$ kasus ibu hamil yang mengalami kurang energi kronik dan pada tahun 2019 sebanyak $1.930 \mathrm{ibu}$ hamil dan terdapat $636(29,5 \%)$ kasus ibu hamil yang mengalami Kurang Energi Kronik. Setiap tahun mengalami peningkatan ibu hamil yang mengalami Kurang Energi Kronik (Profil PKM Sukajadi, 2019).

Berdasarkan uraian diatas maka penulis tertarik untuk melakukan penelitian tentang pemeriksaan status gizi pada ibu hamil sebagai upaya mendeteksi dini kurang energi kronik di Puskesmas Sukajadi Prabumulih.

\section{METODE PENELITIAN}

Desain pada penelitian ini adalah Action Research yaitu peneliti harus mencantumkan plan (perencanaan), do (pelaksanaan), dan see (evaluasi). Pada penelitian ini rencana yang dilakukan diawali dengan penyuluhan tentang kebutuhan gizi pada ibu hamil oleh peneliti. Selanjutnya, pemeriksaan status gizi yang dilakukan pada ibu hamil dengan checklist. Kemudian nilai status gizi dengan pengukuran LILA dan melakukan asuhan gizi pada ibu hamil. Populasi penelitian adalah seluruh ibu hamil yang datang untuk memeriksakan kehamilannya di Puskesmas Sukajadi Prabumulih yang berjumlah 52. Teknik sampling yang digunakan adalah "Purposive Sampling" yaitu pengambilan sampel atas dasar pertimbangan dengan unsur-unsur yang dikehendaki sesuai dengan kriteria inklusi. Adapun jumlah sampel dalam penelitian ini adalah sebanyak 20 orang responden. Instrumen yang digunakan dalam pengumpulan data untuk penelitian adalah komunikasi dua arah, checklist dan observasi diruang KIA Puskesmas Sukajadi Prabumulih untuk mengetahui status gizi ibu hamil dengan melakukan pengukuran LILA sehingga dapat mendeteksi dini kurang energi kronik pada ibu hamil. Analisis data dalam penelitian ini menggunakan analisis univariat dimana tiap variabel dari hasil penelitian dan hanya menghasilkan distribusi frekuensi dan presentasi dari tiap-tiap variabel. 


\section{HASIL DAN PEMBAHASAN}

\section{Hasil}

Tabel 1 Distribusi Frekuensi Berdasarkan Usia Kehamilan

\begin{tabular}{lcc}
\hline \multicolumn{1}{c}{ Usia Kehamilan } & Frekwensi (f) & Prosentase (\%) \\
\hline Trimester I & 2 & $10 \%$ \\
Trimester II & 11 & $55 \%$ \\
Trimester III & 7 & $35 \%$ \\
\multicolumn{1}{c}{ Jumlah } & 20 & $100 \%$ \\
\hline
\end{tabular}

Tabel 1 menunjukkan bahwa sebagian besar usia kehamilan responden berada pada trimester II yaitu 11 orang (55\%) dan sebagian kecil usia kehamilan responden berada pada trimester I yaitu 2 orang $(10 \%)$.

Tabel 2 Distribusi Frekuensi Berdasarkan Pengukuran LILA

\begin{tabular}{cccc}
\hline \multicolumn{2}{c}{ Pengukuran LILA } & Frekwensi (f) & Prosentase (\%) \\
\hline$<23,5 \mathrm{~cm}$ & 13 & $65 \%$ \\
$>23,5 \mathrm{~cm}$ & 7 & $35 \%$ \\
\multicolumn{2}{c}{ Jumlah } & 20 & $100 \%$ \\
\hline
\end{tabular}

Tabel 2 menunjukkan bahwa sebagian besar LILA responden $<23,5 \mathrm{~cm}$ yaitu 13 orang (65\%) dan sebagian kecil LILA responden $>23,5 \mathrm{~cm}$ yaitu 7 orang $(35 \%)$.

Tabel 3 Distribusi Frekuensi Berdasarkan Status Gizi

\begin{tabular}{lccc}
\hline & Status Gizi & Frekwensi & Prosentase (\%) \\
\hline Kurang & & 12 & $60 \%$ \\
Baik & & 8 & $40 \%$ \\
& Jumlah & 20 & $100 \%$ \\
\hline
\end{tabular}

Tabel 3 menunjukkan bahwa sebagian besar status gizi kurang yaitu 12 orang $(60 \%)$ dan sebagian kecil status gizi baik yaitu 8 orang (40\%).

\section{Pembahasan}

Berdasarkan tabel 1, menunjukkan ibu hamil trimester I berjumlah 2 orang (10\%), jumlah ibu hamil trimester II sebanyak 11 orang (55\%), dan Ibu hamil trimester III berjumlah 7 orang (35\%). Selama masa kehamilan, tubuh ibu mengalami perubahan dan menyesuaikan diri dengan tumbuh kembang janin di dalam uterus ibu (Adrian, 2019). Setiap trimester atau tahap kehamilan berlangsung antara 12-14 minggu. Setiap ibu hamil akan merasakan gejala dan perubahan fisik yang mungkin berbeda di tiap trimesternya. Adapun beberapa gejala kehamilan yang biasa terjadi pada Trimester pertama adalah payudara terasa nyeri dan terlihat membengkak, tubuh terasa mudah lelah, mual di pagi hari, emosi cenderung berubah-ubah. Trimester kedua kehamilan berlangsung dari minggu ke 13 hingga ke 27. Sebagian wanita mungkin merasa lebih nyaman jika dibandingkan trimester pertama kehamilan. Pada trimester ketiga merupakan 
tahap kehamilan terakhir yang berlangsung pada minggu ke 28 hingga persalinan. Pada tahap ini, perubahan bentuk tubuh semakin terlihat. Gejala yang dirasakan pada ibu hamil trimester ketiga diantaranya adalah tubuh terasa cepat lelah, susah tidur, kram kaki terjadi lebih sering dari sebelumnya, payudara mengeluarkan cairan, kulit kering dan gatal, terutama dibagian perut. Pemeriksaan kehamilan bertujuan untuk memastikan kehamilan, memeriksa kondisi ibudan janin dalam kondisi baik dan sehat (Wibisono Prio, 2018)

Berdasarkan tabel 2 menunjukkan terdapat $13(65 \%)$ ibu hamil yang memiliki ukuran LILA $<23,5 \mathrm{~cm}$, dan terdapat 7 (35\%) ibu hamil yang memiliki ukuran LILA > 23,5\%. Kurang Energi Kronis (KEK) merupakan kondisi ibu hamil mengalami kekurangan makanan yang berlangsung lama (kronis) sehingga mengakibatkan timbulnya gangguan kesehatan pada ibu (Depkes RI, 2015). Berdasarkan penelitian dari Rahma Putri Ayu dan Al Muqsith tahun 2015, mengatakan bahwa pengukuran LILA lebih baik untuk menilai status gizi ibu hamil karena pada wanita hamil dengan malnutrisi (gizi kurang atau lebih) kadang - kadang menunjukkan edema tetapi ini jarang mengenai lengan atas.

Berdasarkan tabel 3 menunjukkan bahwa sebanyak $12(60 \%)$ ibu hamil yang mengalami status gizi kurang dan terdapat $8(40 \%)$ ibu hamil yang memiliki status gizi baik. Menurut Netty (2017), mengatakan bahwa status gizi merupakan kondisi tubuh sebagai akibat dari pemakaian, penyerapan, dan penggunaan makanan ). Status gizi dapat diketahui melalui pengukuran beberapa parameter, kemudian hasil pengukuran tersebut dibandingkan dengan standar atau rujukan. Peran penilaian status gizi bertujuan untuk mengetahui ada tidaknya status gizi yang salah. Penilaian status gizi menjadi penting karena dapat menyebabkan terjadinya kesakitan dan kematian terkait dengan status gizi. Oleh karena itu dengan diketahuinya status gizi, dapat dilakukan upaya untuk memperbaiki tingkat kesehatan pada masyarakat.

Pada masa kehamilan asupan makanan yang kaya akan nutrisi sangat dibutuhkan untuk perkembangan dan pertumbuhan janin dimulai pada awal trimester I, Trimester II dan Trimester III. Berdasarkan penelitian dari Arisman, 2014 menyebutkan bahwa kelompok ibu hamil rentan mengalami masalah yang berkaitan dengan gizi. Oleh sebab itu, penting untuk menyediakan kebutuhan gizi yang baik selama masa kehamilan agar ibu hamil dapat memperoleh dan mempertahankan status gizi yang optimal. Kualitas bayi yang dilahirkan sangat bergantung pada keadaan gizi ibu sebelum dan selama masa kehamilan (Adriani dan Bambang, 2016). Pada penelitian ini sebanyak 12 (60\%) ibu hamil masuk dalam kategori status gizi kurang dan $8(40 \%)$ ibu hamil masuk dalam kategori status gizi baik. Berdasarkan penelitian dari mengatakan bahwa ada hubungan yang signifikan antara pemeriksaan status gizi ibu hamil dengan deteksi dini Kurang Energi Kronik (KEK). Dengan melakukan pemeriksaan status gizi ibu hamil sebagai upaya deteksi dini Kurang Energi Kronik (KEK) dan apabila dari hasil pemeriksaan tersebut ditemukan kasus KEK selanjutnya petugas kesehatan melakukan pencegahan/pengobatan agar dapat terhindar dari berbagai resiko dan komplikasi KEK yang dapat mengancam kesehatan dan keselamatan baik pada ibu maupun pada janin. Sesuai juga dengan pendapat Evawany (2010: 22) menyatakan bahwa upaya untuk mengurangi kurang energi kronik dengan 
Pemanfaatan KIE (komunikasi Informasi dan Edukasi) pada ibu hamil antara lain penyuluhan tentang kebutuhan gizi ibu hamil, pertumbuhan dan perkembangan janin dalam rahim, resiko dari paritas yang tinggi, tanda-tanda bahaya selama kehamilan dan perawatan diri selama kehamilan agar ibu hamil dapat menjaga kesehatannya dan janin yang dikandung dengan baik

\section{SIMPULAN DAN SARAN}

\section{Simpulan}

Berdasarkan hasil penelitian dan pembahasan diatas dapat disimpulkan bahwa sebagian besar (65\%) ibu hamil memiliki LILA $<23,5 \mathrm{~cm}$ dan ibu hamil dengan status gizi kurang $(60 \%)$. Ada keterkaitan antara ukuran LILA ibu hamil $<23,5 \mathrm{~cm}$ dengan status gizi yang kurang.

\section{Saran}

Disarankan kepada petugas kesehatan untuk meningkatkan program penyuluhan baik di Puskesmas maupun di Posyandu tentang gizi seimbang sehingga ibu hamil lebih meningkatkan konsumsi makanan yang mengandung sumber zat besi seperti sayuran hijau, protein hewani (susu, daging, telur) dan penambahan suplemen zat besi serta memperhatikan gizi dan pola makan sehariharinya agar dapat mengurangi risiko kurang energi kronik pada ibu hamil baik

\section{DAFTAR PUSTAKA}

Adrian, Kevin.2019.Perhatikan Tahap Kehamilan dan Perubahan yang Dilalui Ibu Hamil Berikut ini. https://www.alodokter.com/perhatikan-tahapkehamilan-dan-perubahan-yang-dilalui-ibu-hamil-berikut-ini, diakses 20 Oktober 2020 Jam 19.20 WIB.

Arisman,dr.(2017). Gizi Dalam Daur Kehidupan. ECG. Jakarta

Budi Iswanto dkk.2012. Hubungan Pengetahuan Ibu Hami Tentang Anemia Defisiensi Besi Dengan Kepatuhan Mengkonsumsi Tablet Besi di Puskesmas Karangdowo, Klaten. Jurnal Kesehatan, https://publikasiilmiah.ums.ac.id/handle/11617/3280?show=full ISSN 1979-7621, Vol5 (2) : 110-118. Diakses tanggal 20 Oktober 2020 jam 15.30 WIB

Data Puskesmas Sukajadi.(2019). Profil Puskesmas Sukajadi. Prabumulih

Dinkes Sumsel.2019.Rencana Kinerja Tahunan Dekonsentralisasi. https://erenggar.kemkes.go.id/file2018/e-performance/2-119014-2tahunan581.pdf. Diakses tanggal 19 Oktober 2020 jam 15.45 WIB

Ditjen Kesmas Kemenkes.(2018). Lapoan Kinerja Ditjen Kesehatan Masyarakat Tahun 2017.

https://kesmas.kemkes.go.id/assets/upload/dir_60248a365b4ce1e/files/La poran-Kinerja-Ditjen-KesmasTahun-2017_edit-29-jan-18_1025.pdf.

Diakses tanggal 20 Oktober 2020 jam 08.57 WIB.

.Evawany.(2010). Kebutuhan Gizi Ibu Hamil. IPB Press. Bogor 
Thamaria, Netty (2017). Penilaian Status Gizi. PPSDM Kemenkes RI : 2017. http://bppsdmk.kemkes.go.id/pusdiksdmk/wpcontent/uploads/2017/11/PENILAIAN-STATUS-GIZI-FINAL-SC.pdf. Diakses tanggal 19 November 2020 Jam 10.00 WIB

Rahma Putri Ayu dan Al Muqsith.2015. Hubungan Lingkar Lengan Atas Ibu Hamil dengan Berat Badan Lahir Bayi di Rumah Sakit Umum Cut Meutia Kabupaten Aceh Utara dan Rumah Sakit Tk I M.07.01 Lhokseumawe Tahun 2015. https://ojs.unimal.ac.id/index.php/averrous/article/view/399. p-ISSN 2477-5231 e-ISSN 2502-8715, Vol 2 No 1 Mei 2016. Diakses tanggal 2 November 2020 jam 17.00WIB.

Suhaeti, 2018. Faktor-faktor yang berhubungan dengan status gizi ibu hamil di Wilayah Kerja Puskesmas Lalundu Kabupaten Donggala. https://jurnal.unismuhpalu.ac.id/index.php/jom/article/view/402, p-ISSN 2089-0346 e-ISSN 2503-1139, Vol 1 No 12018 Diakses tanggal 30 Oktober 2020 jam 19.00 WIB.

Tanawani.2015.Hubungan Pola Makan dan Pola Kerja Bumil dengan Kejadian Anemia di Kecamatan Yapen Selatan Kabupaten Yapen Waropen.Thesis, Universitas Gajah Mada.

Waryana (2010). Gizi Reproduksi. Pustaka Rihama. Yogyakarta

Wibisono, Prio. 2018. Antenatal Care, Pemeriksaan Kehamilan Demi Keselamatan Ibu dan Janin. https://skata.info/article/detail/195/antenatalcare-pemeriksaan-kehamilan-demi-keselamatan-ibu-dan-janin. Diakses tanggal 01 November 2020 jam 16.00WIB. 